\title{
Production and characterization of acetic fermentation with different fruit peels
}

\author{
Produção e caracterização da fermentação acética com diferentes cascas de frutas \\ Producción y caracterización de fermentación acética con diferentes cáscaras de frutas
}

Received: 10/16/2021 | Reviewed: 10/21/2021 | Accept: 10/23/2021| Published: 10/25/2021

Sérgio Luis Melo Viroli
ORCID: https://orcid.org/0000-0003-3982-1183
Instituto Federal de Educação, Ciências e Tecnologia do Tocantins, Brasil
E-mail:viroli @ifto.edu.br
Sérgio Guimarães Viroli
ORCID: https://orcid.org/0000-0002-6558-5391
Universidade Federal do Tocantins, Brasil
E-mail: sergio.viroli@ @ail.uft.edu.br
Nelson Pereira Carvalho
ORCID: https://orcid.org/0000-0002-7637-1292
Instituto Federal de Educação, Ciências e Tecnologia do Tocantins, Brasil
E-mail: nelson.pereira.carvalh@ @mail.com
Delma Pereira da Silva Bernardi
ORCID: https://orcid.org/0000-0001-9932-1776
Universidade Federal do Tocantins, Brasil
E-mail: delmahumor@gmail.com
Rachel Gomes Coelho
Instituto Federal de Educação, Ciências e Tecnologia do Tocantins, Brasil
E-mail:rachelcoelho21@ @mail.com

\begin{abstract}
Acetic fermentation or vinegar is the product obtained from fermented alcoholic wort, cereals or hydroalcoholic mixture with a minimum volatile acidity of $4 \mathrm{~g} / 100 \mathrm{~m} . \mathrm{L}^{-1}$. The present study produced, characterized and correlated the total dry extract with the density of the acetic fermented produced from the pineapple and apple peels. The fermentation process used pineapple and apple peel with culture medium, 10\% hydroalcoholic solution, room temperature between $28 \pm 2^{\circ} \mathrm{C}$ and irrigation 4 (four) times a day, without aeration for 12 days. Physico-chemical determinations of volatile acidity, density, dry extract, $\mathrm{pH}$ and alcohol content at $20^{\circ} \mathrm{C}$ were performed. The ANOVA variance analysis and the 5\% Tukey test identified a difference between the analyzed acetic fermented. The acetic fermentations analyzed showed results within the established by Brazilian legislation. The relationship between the physical-chemical variables and the acetic fermented was studied by Principal Component Analysis (PCA). It was obtained that, with 5 components, more than $97.9 \%$ of the variability of the data were explained. There was a significant correlation between dry extract and vinegar density. The acetic fermented produced have similar physicalchemical characteristics to those produced industrially, which makes them suitable for consumption as commercial vinegars.
\end{abstract}

Keywords: Family farming; Fruit; Reuse; Agro-industrial waste.

\section{Resumo}

A fermentação acética ou vinagre é o produto obtido a partir de mosto alcoólico fermentado, cereais ou mistura hidroalcoólica com acidez volátil mínima de $4 \mathrm{~g} / 100 \mathrm{~m} \cdot \mathrm{L}^{-1}$. O presente estudo produziu, caracterizou e correlacionou o extrato seco total com a densidade do fermentado acético produzido a partir das cascas de abacaxi e maçã. O processo de fermentação utilizou casca de abacaxi e maçã com meio de cultura, solução hidroalcoólica a 10\%, temperatura ambiente entre $28 \pm 2^{\circ} \mathrm{C}$ e irrigação 4 (quatro) vezes ao dia, sem aeração por 12 dias. Foram realizadas determinações físico-químicas de acidez volátil, densidade, extrato seco, $\mathrm{pH}$ e teor de álcool a $20^{\circ} \mathrm{C}$. A análise de variância ANOVA e o teste de Tukey a 5\% identificaram diferença entre os fermentados acéticos analisados. As fermentações acéticas analisadas apresentaram resultados dentro do estabelecido pela legislação brasileira. A relação entre as variáveis físico-químicas e o fermentado acético foi estudada por Análise de Componentes Principais (PCA). Obteve-se que, com 5 componentes, mais de $97,9 \%$ da variabilidade dos dados foram explicados. Houve uma correlação significativa entre o extrato seco e a densidade do vinagre. Os fermentados acéticos produzidos possuem características físicoquímicas semelhantes aos produzidos industrialmente, o que os torna adequados para consumo como vinagres comerciais.

Palavras-chave: Agricultura familiar; Fruta; Reuso; Resíduos agroindustriais. 


\begin{abstract}
Resumen
La fermentación acética o vinagre es el producto obtenido a partir de mosto alcohólico fermentado, cereales o mezcla hidroalcohólica con una acidez volátil mínima de $4 \mathrm{~g} / 100 \mathrm{~m} . \mathrm{L}^{-1}$. El presente estudio produjo, caracterizó y correlacionó el extracto seco total con la densidad del producto acético fermentado producido a partir de cáscaras de piña y manzana. El proceso de fermentación utilizó cáscara de piña y manzana con medio de cultivo, solución hidroalcohólica al $10 \%$, temperatura ambiente entre $28 \pm 2{ }^{\circ} \mathrm{C}$ y riego 4 (cuatro) veces al día, sin aireación durante 12 días. Se realizaron determinaciones fisicoquímicas de acidez volátil, densidad, extracto seco, $\mathrm{pH}$ y contenido de alcohol a $20^{\circ} \mathrm{C}$. El análisis de varianza ANOVA y la prueba de Tukey al $5 \%$ identificaron diferencias entre los fermentados acéticos analizados. Las fermentaciones acéticas analizadas presentaron resultados dentro de lo establecido por la legislación brasileña. La relación entre las variables fisicoquímicas y la fermentación acética se estudió mediante el Análisis de Componentes Principales (PCA). Se encontró que, con 5 componentes, se explicaba más del 97,9\% de la variabilidad de los datos. Hubo una correlación significativa entre el extracto seco y la densidad del vinagre. Los productos fermentados acéticos producidos tienen características físicoquímicas similares a los producidos industrialmente, lo que los hace aptos para su consumo como vinagres comerciales.
\end{abstract}

Palabras clave: Agricultura familiar; Fruta; Reutilizar; Resíduos agroindustriales.

\title{
1. Introduction
}

Fermentation can be defined in a general sense as any transformation process produced from microorganisms that occurs in the presence or absence of air (Jones et al., 2019, Viana et al, 2017). Fermentation is the biochemical process in which microorganisms remove the nutrient material they need from the medium in which they live, producing substances, under the catalytic action of enzymes, which the industry uses (Viana et al, 2017, Evangelista, 2008). Fermentation produces a variety of products, such as food, beverages, organic acids, solvents, esters, amino acids, enzymes, polysaccharides, vitamins, antibiotics and hormones (Cunha, 2010). Among the fermentative processes, alcoholic, acetic and lactic fermentation stand out. These processes break the substrate into pyruvate and convert it into another product, such as ethanol, acetic acid, lactic acid. Acetic fermentation consists of converting ethyl alcohol into ethanoic acid (acetic acid) by means of acetic bacteria.

Acetic bacteria belong to a class of microorganisms of broad economic interest, both because of the production of ethanoic acid and because of changes in food and drink. (Hoffmann, 2006). These organisms have excellent adaptation to sugary environments. Its ability to convert ethyl alcohol into ethanoic acid is one of the characteristics that popularized its use in the production of vinegars (Bartowysky \& Henschk, 2008). Acetic fermented or vinegar is the product obtained from the acetic fermentation of the alcoholic fermented fruit must, cereals, sugary products, vegetables, honey, vegetable mixture or hydroalcoholic mixture with a minimum volatile acidity of $4 \mathrm{~g} / 100 \mathrm{~m} . \mathrm{L}^{-1}$, expressed in acetic acid. The acetic fermented can have several classifications, according to the origin of the raw material, being called acetic fermented or vinegars, followed by the name of the raw material of origin. They can present optional ingredients such as herbs, spices, salt, among others, in sufficient quantities to impart a peculiar aroma and flavor (Brasil, 2012).

Brazilian vinegars are produced from ethyl alcohol, constituting a 4\% acetic acid solution, this acid concentration being the minimum required by law, with the addition of an antioxidant that acts as a stabilizer (Netto, 2006). In Brazilian territory, the manufacture of vinegar with dilution of ethanoic acid of non-fermentative origin is prohibited. For concentrated vinegars, the same characteristics will apply, respecting the proportions of concentration (Brasil, 2012, Aquarone et al., 2001). Vinegar can be produced by consecutive processes of alcoholic and acetic fermentation. In the first, the carbohydrate is converted into ethyl alcohol and in the second, fermentative oxidation occurs which turns ethyl alcohol into ethanoic acid. (Veloso, 2013, Schmoeller, 2011). Deformed or non-standard fruits are discarded after harvest. In this way, these fruits can be used to manufacture vinegar. (Ubeda et al., 2011, Evangelista, 2008, Bortolini, Sant'anna \& Torres 2001).

Fruit peels represent a good option for the production of vinegar, as they have a large amount of soluble solids and nutrients (Paganini et al., 2003). The manufacture of vinegar using fruit peels represents an alternative to add commercial value to deformed, injured or advanced ripening fruits. (Abud, Silva \& Araújo, 2012, Tessaro et al., 2010, Santos et al., 2008). 
Thus, this research aimed to produce, characterize and correlate the total dry extract with the densities of the acetic fermented obtained from the pineapple and apple peels by slow spontaneous fermentation.

\section{Methodology}

During the months of April and May of the year 2020, PET bottles were purchased in snack bars and pizzerias in the Municipality of Paraíso do Tocantins. The bottles were used in the construction of a reactor (Figures 1 and 2) for the production of acetic fermented pineapple and apple peels. The reactor was developed according to a flow chart (Figure 1), applying the method used by Santos et al. (2008).

Figure 1. Flowchart of the reactor construction (PET bottle) for acetic fermentation of fruit peels.

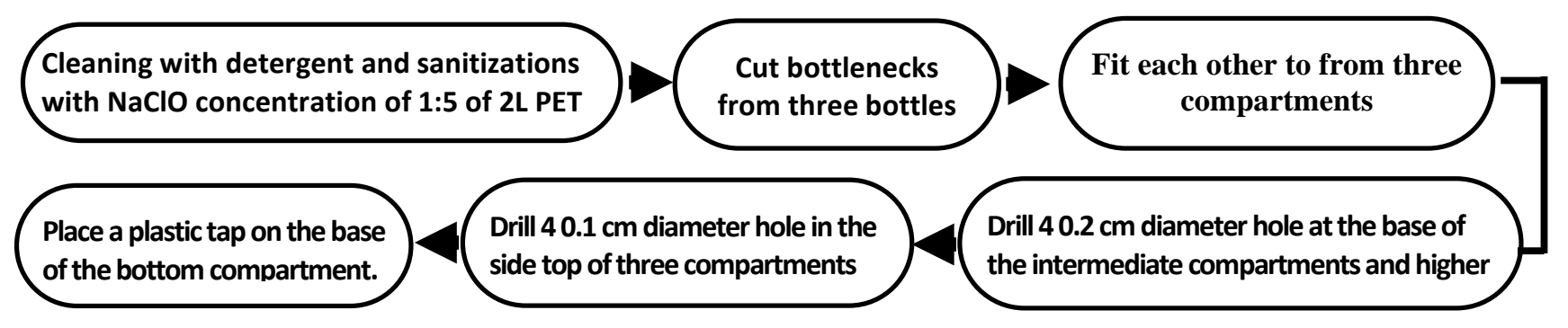

Source: Santos et.al. (2008).

Figure 2. (A) - Sanitization of PET bottles. (B) - Removal of the neck of the PET bottle. (C) - Holes at the base of the intermediate and upper compartments and (D) - Fit the bottles together to form the reactor.

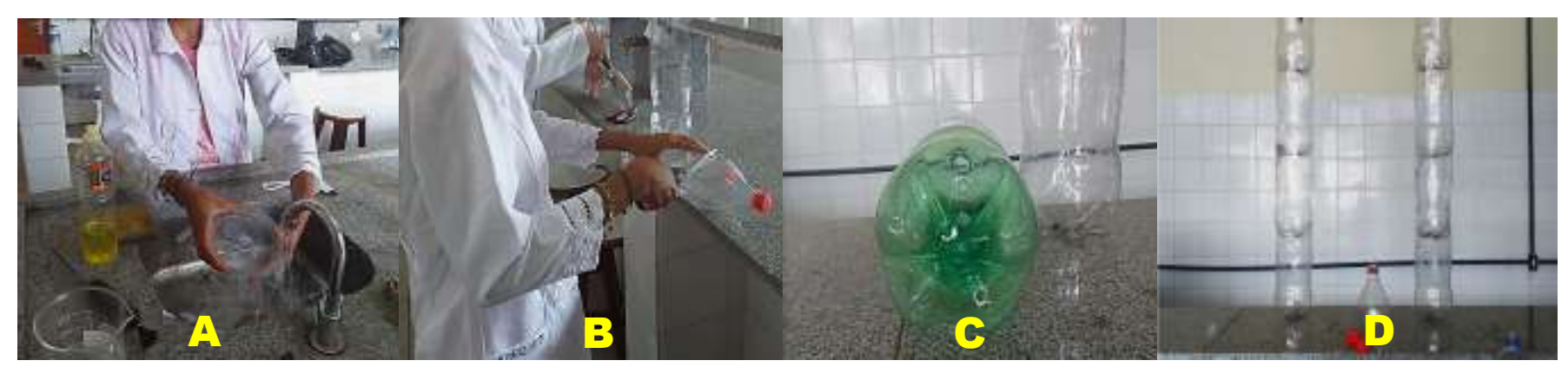

Source: Authors (2021).

The experiment was carried out at the processing and vegetable unit of the Federal Institute of Education of Tocantins - IFTO: Campus Paraíso. Pineapples (Ananas comosus) and gala apples (Red delicious), used for the production of acetic fermented, were purchased in supermarkets and fruit stores in the Municipality of Paraíso do Tocantins. Pineapples were purchased according to the maturation stages "B" and " $\mathrm{C}$ " in Figure 3 and apples according to the classification "C" and "D" in Figure 4 . 
Figure 3. Pineapple classification.

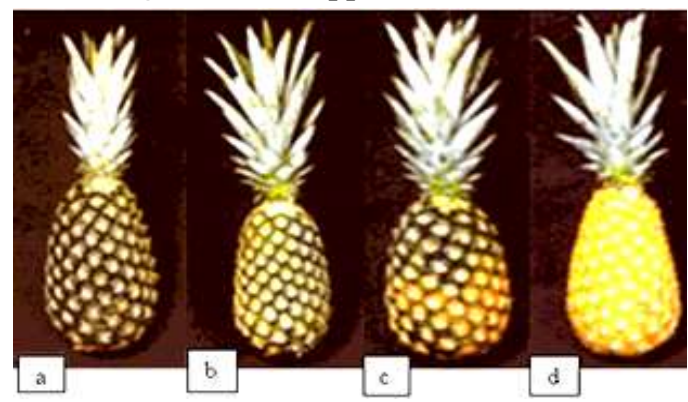

Source: https: //www.monografia.com/pt/ trabalhos2/processed-foods/ processed-foods2.shtml

Figure 4. Apple classification.

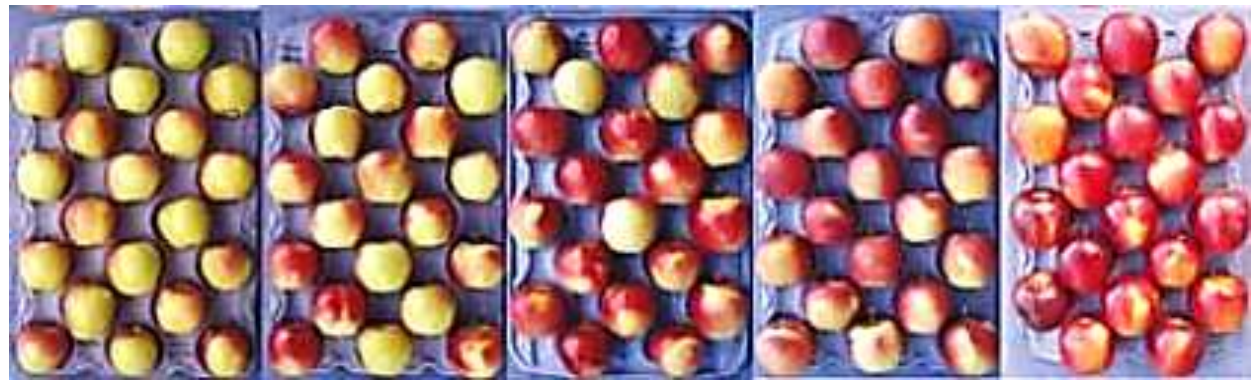

Source: Betinelli (2017).

The fermentation process was developed using 2 liters of $10 \%$ hydroalcoholic solution (v/v), $2 \mathrm{~kg}$ of pineapple peel and $1 \mathrm{~kg}$ of apple peel. Fruit peels were used as a culture medium, as they are a source of microorganisms that transform alcohol into acetic acid. The irrigation system used was the introduction of the alcoholic solution at the top of the reactor and after 2 hours, the liquid was collected by the tap at the base of the reactor. This process was repeated 6 (six) times a day for 12 days at room temperature between $28 \pm 2{ }^{\circ} \mathrm{C}$ without aeration (Santos et al., 2008). After the fermentation process, the acetic fermentates produced by the slow fermentation process were filtered, stored and sterilized in a glass container. The physicochemical determinations used for the determination of volatile acidity $\left(\mathrm{g} \cdot \mathrm{mL}^{-1}\right)$, density at $20^{\circ} \mathrm{C}\left(\mathrm{g} \cdot \mathrm{mL}^{-1}\right)$, dry extract $\left(\mathrm{gL}^{-1}\right)$, hydrogen potential and alcohol content at $20^{\circ} \mathrm{C}\left(\% \mathrm{v} \cdot \mathrm{v}^{-1}\right)$ followed the methodological procedures of Instituto Adolfo Lutz (Instituto Adolfo Lutz, 2008).

The physicochemical, acidity, density, dry extract, hydrogen potential and alcohol content analyzes were processed in quadruplicate and their results submitted to analysis of variance. To verify whether there was a significant difference between the results, ANOVA and Tukey's test were applied with a significance level of 5\% between the means of the response variables. Statistical correlation between total dry extract and relative density at $20{ }^{\circ} \mathrm{C}$ was performed using Microsoft Excel for Windows (2003). The Principal Component Analysis (PCA) analyzed the data in which the treatments are related by interrelated response variables, where the objective was to group the physical-chemical variables by similarity. Principal Component Analysis (PCA) was used to group physical and chemical variables according to similarity. PCA was performed on standardized data to avoid the effect of different magnitude levels of response variables. Data standardization for each response variable was performed by subtracting each value by its mean divided by the standard error. All statistical analyzes were performed using Sisvar version 5.6 (Ferreira, 2019). The ACP analysis was performed with the PAST software (Hommer, Harper \& Ryan, 2001). 


\section{Results and Discussion}

The results of the physical-chemical parameters analyzed for the acetic fermented produced with pineapple (FAC pineapple) and apple (FAC apple) peels compared to commercial red wine vinegar (VCVT) are shown in Table 1.

Table 1. Physical-chemical characteristics of artisanal fermented fermenters compared to commercial vinegar.

\begin{tabular}{|c|c|c|c|c|c|}
\hline Vinegar & $\begin{array}{l}\text { Acidity } \\
\left(\mathrm{g} \cdot \mathrm{mL}^{-1}\right)\end{array}$ & $\begin{array}{c}\text { Density } \\
20^{\circ} \mathrm{C}\left(\mathrm{g} \cdot \mathrm{mL}^{-1}\right)\end{array}$ & $\begin{array}{l}\text { Dry extract } \\
\quad\left(\text { g. } \mathrm{L}^{-1}\right)\end{array}$ & $\begin{array}{c}\text { Hydrogen } \\
\text { potential pH }\end{array}$ & $\begin{array}{c}\text { Alcohol content } \\
\%(\mathrm{v} / \mathrm{v})\end{array}$ \\
\hline VCVT & $4.42^{\mathrm{C}} \pm 0,007$ & $1.0125^{\mathrm{A}} \pm 0,000$ & $10.59^{\mathrm{A}} \pm 0,006$ & $2.74^{\mathrm{B}} \pm 0,006$ & $0.59^{\mathrm{A}} \pm 0,006$ \\
\hline FAC pineapple & $4.53^{\mathrm{B}} \pm 0,004$ & $1.0109^{\mathrm{C}} \pm 0,000$ & $6.90^{\mathrm{C}} \pm 0,015$ & $2.91^{\mathrm{A}} \pm 0,008$ & $0.45^{\mathrm{B}} \pm 0,010$ \\
\hline FAC apple & $4.55^{\mathrm{A}} \pm 0,010$ & $1.0120^{\mathrm{B}} \pm 0,000$ & $8.80^{\mathrm{B}} \pm 0,005$ & $2.71^{\mathrm{C}} \pm 0,005$ & $0.28^{C} \pm 0,006$ \\
\hline C. V $(\%)$ & 0.16 & 0.01 & 0.11 & 0,24 & 1,33 \\
\hline Legislation* & $\geq 4,0\left(\mathrm{~g} \cdot \mathrm{mL}^{-1}\right)$ & --------------------. & $\geq 6,0\left({\mathrm{~g} . \mathrm{L}^{-1}}^{-1}\right)$ & --------------------. & $\leq 1,0(\% \mathrm{v} / \mathrm{v})$ \\
\hline
\end{tabular}

Equal letters in the columns mean that the types of acetic fermented did not differ from each other $(\mathrm{P}>0.05)$ by the Tukey test. C.V (\%) coefficient of variation.

* Normative Instruction $\mathrm{N}^{\circ}$. 6/2012 of MAPA

Source: Authors (2021).

According to the analysis in Table 1, it is observed that for all variables studied, acidity, density, total dry extract, $\mathrm{pH}$ and alcohol content indicate that the samples showed heterogeneity based on the Tukey test at $5 \%$ significance. There was a significant difference $(\mathrm{P} \leq 0.05)$ between the acetic fermented pineapple, apple and commercial red wine vinegar.

The acetic fermented produced with pineapple and apple peels from an artisanal process showed significant differences at the level of $5 \%$ in relation to Commercial Vinegar from the large-scale production industry, indicating the influence of the type of processing on the final quality of the product. The results obtained for the physical and chemical analyzes showed values in accordance with Normative Instruction No. 6, of April 3, 2012 from the Ministry of Agriculture, Livestock and Supply (Brasil, 2012). The density and hydrogen potential do not have limits specified in the referred legislation.

Acidity influences the sensory acceptance of the product, since the percentage of acetic acid in the acetic fermented is directly proportional to the sensorially perceived acidity (Granada, Mendonça et al. 2000; Tesfaye et al., 2002). Rizzon \& Miele (1998) found average volatile acid values of $4.4 \%$ for red wine vinegar and $4.3 \%$ for white wine vinegar. Silva et. al. (2008), reusing fruit peels for the production of vinegar found acidity in the acetic fermented produced with the pineapple peels equal to $4.55 \pm 0.15$ (g.mL $\left.L^{-1}\right)$ and $4.54 \pm 0.08\left(\mathrm{~g} \cdot \mathrm{mL}^{-1}\right)$ for apple. Moreira, and contributors (2017), developing acetic fermentation with pineapple peel, found acidity of $1.3 \mathrm{~g} . \mathrm{mL}^{-1}$. Viroli, and contributors (2021), producing artisanal fermented acetic acid with apple peel found a value of $4.56 \pm 0.01$ g.mL $\mathrm{mL}^{-1}$ for volatile acidity.

The relative density at $20^{\circ} \mathrm{C}$ is based on the relationship between the specific weight of the sample at $20^{\circ} \mathrm{C}$ in relation to the specific weight of water at $20^{\circ} \mathrm{C}$. As for density, Rizzon \& Miele (1998) found lower values from the analytical characterization of commercial acetic fermented wines from Brazil, with $1.0103 \mathrm{~g} \mathrm{~mL}^{-1}$ being acetic fermented red wines and 1,0009 g.mL $\mathrm{m}^{-1}$ of wine white. Moreira, and contributors (2017), found a density value of $1009.9 \mathrm{~g} / \mathrm{L}$ in acetic fermented produced with pineapple peel. Viroli et. al. (2021) found a density value of $1.0108 \pm 0.0200 \mathrm{~g} \cdot \mathrm{mL}^{-1}$ in acetic fermentation with apple.

The determination of the dry extract of acetic fermented is an attempt to avoid fraud that has been widely used in the past, since very low or very high levels of dry extract may indicate adulteration of the product (Takemoto, 2000). The dry extract value for the acetic fermented pineapple found in this work was lower than that reported by Diniz (2017) who found for the total dry extract of the fermented pineapple peel 44.02 g.L.-1. Marques, and contributors (2010), evaluating the identity and 
quality standards of commercial acetic fermented fruits and vegetables found values for the total dry extract of the fermented apple equal to $8.9 \pm 0.311 \mathrm{~g} . \mathrm{L}^{-1}$, which is also very close to the value of this study. Rizzon and Miele (1998), studying the analytical characteristics of commercial acetic fermented produced with red wine, found values for the dry extract equal to 9.78 g.L $L^{-1}$, a value lower than that found in this study.

Pedroso (2003) evaluating the acetic fermented apple found a variation of $3.10 \pm 0.26$ for the $\mathrm{pH}$. Marques et al. (2010) found variations in $\mathrm{pH}$ values for the acetic fermented red wine equal to $2.69 \pm 0.045$ and $3.10 \pm 0.017$ for the acetic fermented apple. Santos et al. (2008), found $\mathrm{pH}$ variations equal to $2.72 \pm 0.04$ for the acetic fermented produced with apple and $2.78 \pm 0.13$ for the acetic fermented with the pineapple peels. The $\mathrm{pH}$ found by Santo et al is higher than the $\mathrm{pH}$ found in this study. Moreira, and contributors (2017) found a pH value equal to 3, 9 for the acetic fermented produced with pineapple peel.

Viroli et al. (2021) found alcohol content of acetic fermented produced with apple equal to $0.21 \pm 0.01$ (\% v.v $\left.\mathrm{v}^{-1}\right)$. Santos et al. (2008) found variations in the alcohol content for the acetic fermentation of pineapple and apple equal to $0.25 \pm$ $0.08\left(\%\right.$ v. $\left.\mathrm{v}^{-1}\right)$ and $0.43 \pm 0.12\left(\% \mathrm{v} \cdot \mathrm{v}^{-1}\right)$, respectively. Marques, et al. (2010), analyzing the alcoholic content in acetic fermented apple found a value of $0 \%$ in the analyzed samples. Possibly, the methodology used by the authors to determine the alcohol content was not sensitive enough to detect the low concentrations of alcohol in the acetic fermented.

According to White (1971) and Marques et al. (2010), an efficient conversion occurs with the transformation of 70\% of alcohol into acid, reaching an efficiency of 90 to $98 \%$. The statistical correlation between the values of dry extract and density resulted in a correlation coefficient $\mathrm{R}^{2}$, which represents the existence of a significant correlation $(\mathrm{P} \leq 0.01)$ between the two physical and chemical parameters analyzed. The dry extract and the density of the acetic fermented are directly proportional. The graph below (Figure 05) shows a linear regression between the two determinations, with a coefficient $\left(\mathrm{R}^{2}\right)$ of 0.9621 , corroborating the existence of linearity between the dry extract content and sample density.

Figure 5. Relationship between values of density relative to $20^{\circ} \mathrm{C}\left(\mathrm{g} \cdot \mathrm{mL}^{-1}\right)$ and dry extract $\left(\mathrm{g} \cdot \mathrm{L}^{-1}\right)$ of the analyzed acetic fermented.

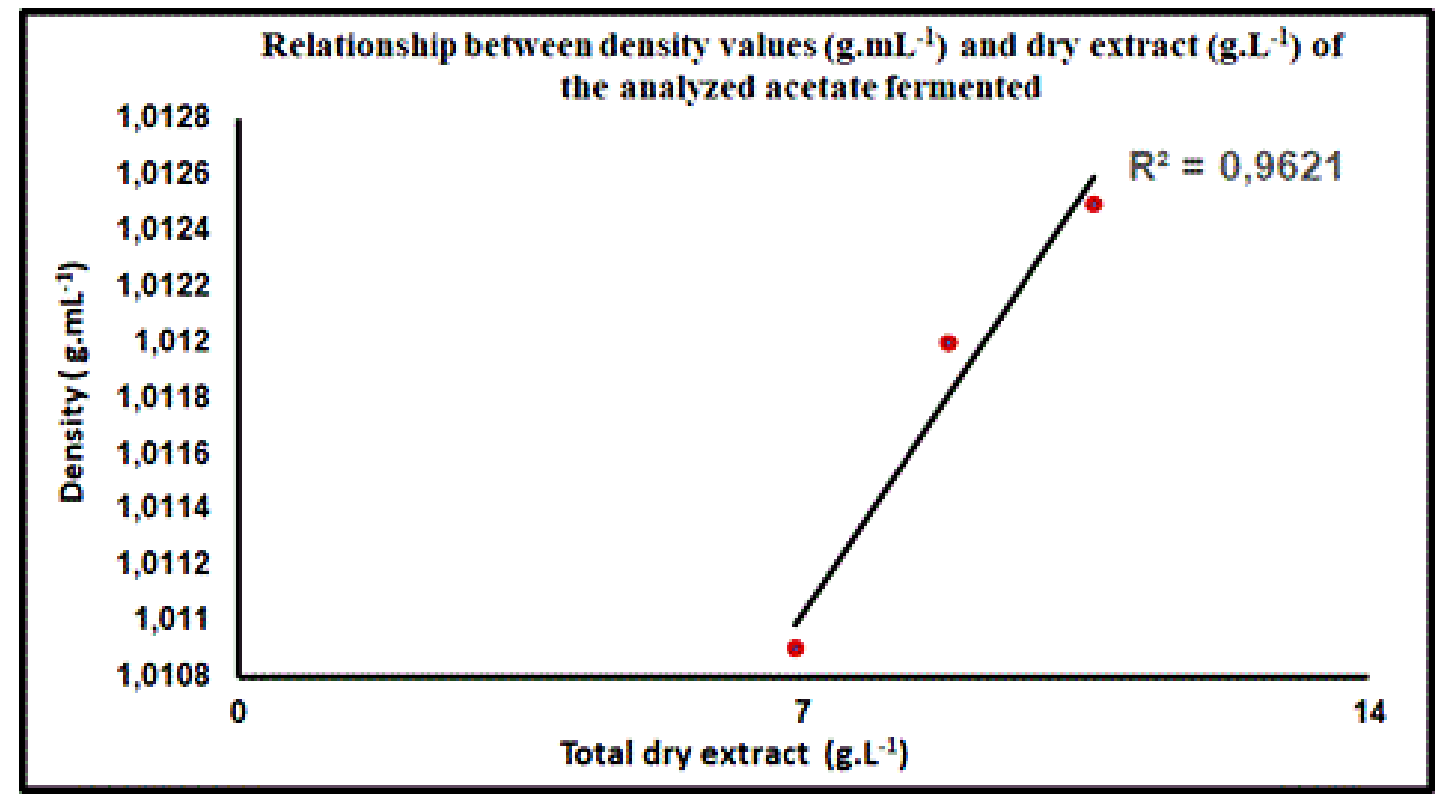

Source: Authors (2021).

Marques (2008), researching on physical-chemical, nutritional and sensory characteristics of vinegars of different raw materials, found a value for linear relationship $\left(\mathrm{R}^{2}\right)$ between the density values at $20{ }^{\circ} \mathrm{C}$ and the extract equal to 0.8580 . Lira 
(2004) states that a linear correlation is classified as very strong when the modules of the values of the correlation coefficient are between 0.90 and 1.0. Thus, according to the author's classification, the result of the $\mathrm{R}^{2}$ found by Marques showed a strong correlation, while the $\mathrm{R}^{2}$ found for the correlation between density and dry extract is classified with a lot strong.

The Table 2 describes the weights of the main components CP1 and CP2 for all variables studied.

Table 2. Description of the main components CP1 and CP2 for the physical and chemical variables analyzed.

\begin{tabular}{lcc}
\hline \multicolumn{1}{c}{ Variable } & PC1 & PC2 \\
\hline Acidity $\%(\mathrm{p} / \mathrm{v})$ & -0.50441 & -0.22557 \\
Density $20^{\circ} \mathrm{C}(\mathrm{g} / \mathrm{mL})$ & 0.50059 & -0.11412 \\
Dry extract $(\mathrm{g} / \mathrm{L})$ & 0.51746 & -0.053882 \\
Hydrogen potential $\mathrm{pH}$ & -0.40305 & 0.5658 \\
Alcohol content \% $(\mathrm{v} / \mathrm{v})$ & 0.25451 & 0.78298 \\
\hline
\end{tabular}

Source: Authors (2021).

Principal Component Analysis (PCA) provided a simplified interpretation (Figure 6) of the relationships between the response variables as well as the samples, facilitating the visualization of the response variables and correlating them. The main components CP1 and CP2 (orthogonal axes) explained $97.79 \%$ of the total data variability (Table 03), $73.08 \%$ being explained by the first component and $24.82 \%$ by the second component. The sum of main components I and II ( $\geq 75 \%$ ) adequately presented the variability between the samples (Abdi \& Williams, 2010).

Figure 6. Analysis of main components of acetic fermented handcrafted compared to commercial vinegar.

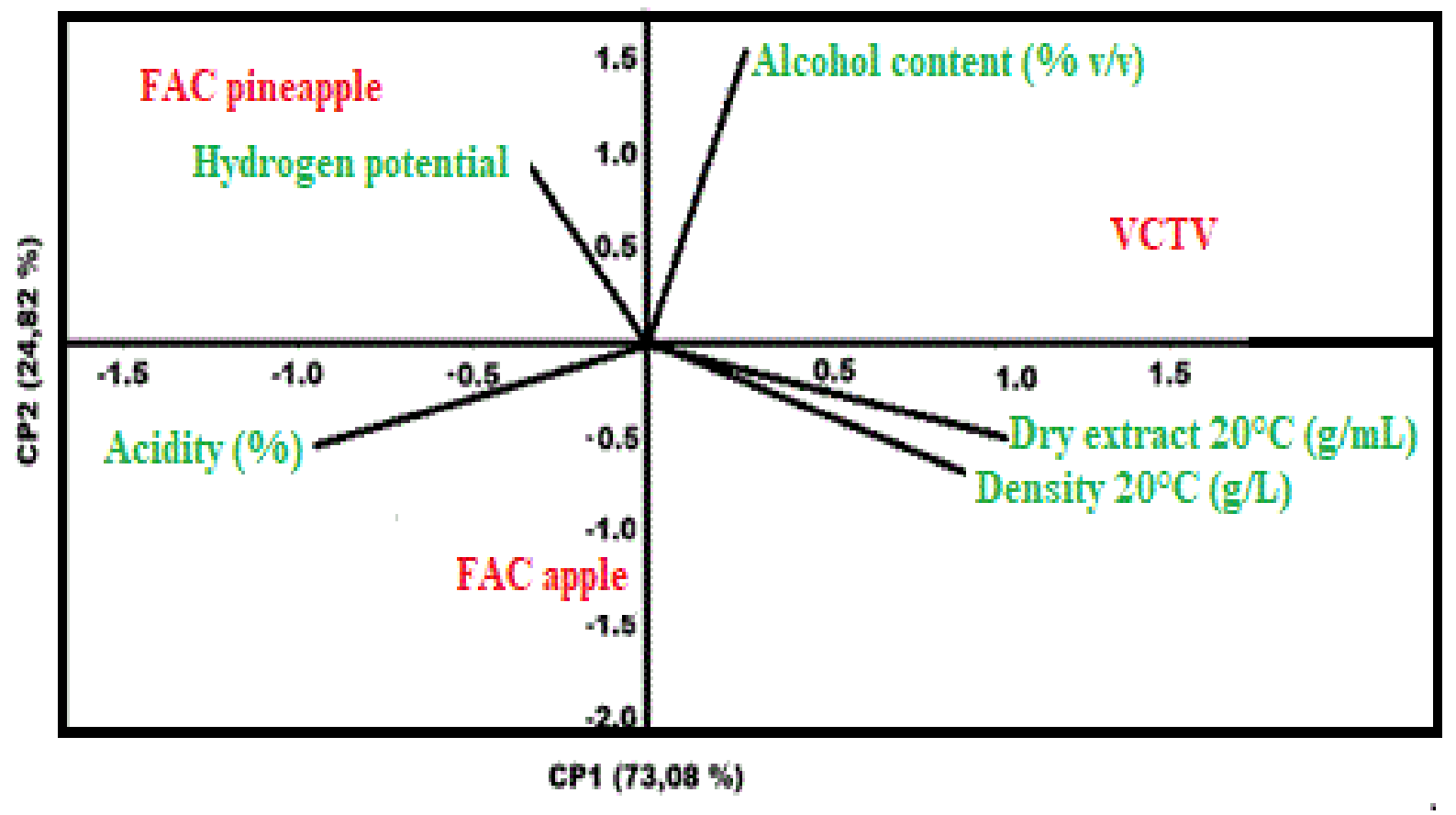

VCTV- commercial red wine vinegar.

FAC-pineapple-fermented acetic pineapple peel

FAC apple - fermented acetic apple peel.

Source: Authors (2021). 
Table 3. Principal components (CP), eigenvalues (Eigenvalue) and percentage of explained variance.

\begin{tabular}{ccc}
\hline PC & Eigenvalue & \% Variance \\
\hline 1 & 3.65707 & 73.08 \\
2 & 1.24204 & 24.82 \\
3 & 0.0974318 & 1.947 \\
4 & 0.0053429 & 0.10677 \\
5 & 0.00228256 & 0.045613 \\
\hline
\end{tabular}

Source: Authors (2021).

According to Figure 6, the treatments VCTV, FAC pineapple and FAC apple are respectively in the upper right, upper left and lower left areas of the graph. According to Table 3 and Figure 6, in the first main component CP1, the variables acidity, density and dry extract stood out and for the second main component CP2 the alcohol content and $\mathrm{pH}$. There is a high correlation between the variables density and dry extract. This high correlation was verified by forming acute angles between them, a vector of greater length and proximity to the CP1 axis. The VCVT Treatment was related to the highest values of alcohol content, density and dry extract and lower acidity. The FAC pineapple treatment was related to the highest $\mathrm{pH}$ and the FAC apple treatment to the highest acidity.

\section{Conclusion}

The acetic fermentation production process showed ease of assembly, production and a small amount of input for the production of vinegar. The acetic fermentation produced with fruit peels in a reactor produced with PET bottles, showed physical-chemical characteristics similar to the fermented ones produced industrially, which made them apt to be commercialized and consumed as vinegars.

It is suggested that new studies on the production of vinegar with fruit peels be carried out to promote the generation of family income and local economic development.

\section{Acknowledgments}

To God, to the Federal Institute of Education, Science and Technology of Tocantins (IFTO) Campus Paraíso of Tocantins for the support given during the development of the stages of this work.

\section{References}

Abdi, H., \& Williams, L. J. (2010). Principal component analysis. Wires Computational Statistics. 2(4), 433-459. https://doi.org/10.1002/wics.101

Abud, A. K. S., Silva, C. E. F., \& Araújo, 1. T. (2012). Produção de vinagre de laranja "lima” em vinagreira artesanal. Scientia Plena, Aracaju, 8(12). https://www.scientiaplena.org.br/sp/article/view/1077/633.

Aquarone, E., Borzani, W., Schmidell Netto, W., \& Lima, U. de A. (2001). Biotecnologia industrial: biotecnologia na produção de alimentos. Edgard Blucher.

Bartowysky, E. J., \& Henschke, P. A. (2008). Acetic acid bacteria spoilage of bottled red wine - A review. International Journal of Food Microbiology, 1(25), 60-70. DOI: 10.1016/j.ijfoodmicro.2007.10.016

Betinelli, K. S.; Martin, M. S. de; Argenta, L. C.; Amarante, C. V. T. do, \& Denardi, F. Estádio de maturação para colheita de maçãs 'scs426 venice'. Agropecuária Catarinense, 30(2), 57-62, maio/ago. 2017. https://publicacoes.epagri.sc.gov.br/RA/article/view/41/128.

Bortolini, F., Sant'anna, E. S., \& Torres, R. C. (2001). Comportamento das fermentações alcoólica e acética de sucos de kiwi (actinidia deliciosa); composição dos mostos e métodos de fermentação acética. Ciência Tecnologia Alimentos. 21(2), 236-243. https://doi.org/10.1590/S0101-20612001000200020 
Brasil. Ministério da Agricultura Pecuária e Abastecimento (2012). Instrução Normativa $n^{\circ} 6$ de abril de 2012. Estabelece os padrões de identidade e qualidade e a classificação dos fermentados acéticos. Diário Oficial da União República Federativa do Brasil, Brasília, DF. https://www.gov.br/agricultura/ptbr/assuntos/inspecao/produtos-vegetal/legislacao-1/bebidas.

Cunha, M. A. A. (2010). Tecnologia das Fermentações. Apostila (Curso de Graduação em Química). Universidade Tecnológica Federal do Paraná, Pato Branco.

Diniz, M. P. F. (2017). Aproveitamento da casca de abacaxi no preparo de fermentado alcoólico. Trabalho de Conclusão de Curso. Instituto Federal de Educação, Ciência e Tecnologia de Sergipe. São Cristóvão. https://repositorio.ifs.edu.br/biblioteca/bitstream/123456789/648/1/Mith\%20Phillpe\%20Ferreira\%20Diniz.pdf.

Evangelista, J. (2008). Tecnologia de alimentos. (2a ed.), Atheneu.

Ferreira, D. F. (2019). SISVAR: A computer analysis system to fixed effects split plot type designs. Revista Brasileira de Biometria, 37(4), 529-535. https://doi.org/10.28951/rbb.v37i4.450.

Granada, G. G., Mendonça, C. R. B., Rosa, V. P., \& Zambiazi, R. C. (2000). Vinagres de folhas de videira: aspectos sensoriais. Boletim do CEPPA, 18(1), p. 51-56, 2000. https://revistas.ufpr.br/alimentos/article/view/1124/925.

Hoffmann, A. (2006). Embrapa Uva e vinho. Sistema de produção de Vinagre. http://www.cnpuv.embrapa.br/publica/sprod/Vinagre/legislacao.html.

Hommer, O., Harper, D.A.T., \& Ryan, P.D. (2001). PAST: Paleontological statistics software package for education and data analysis. Paleontol. Elet. 4(1):9. http://palaeo-electronica.org/2001_1/past/issue1_01.htm

Instituto Adolfo Lutz. (2018). Métodos físico-químicos para análise de alimentos. IV ed.

Jones, M., Arnaud, E., Gouws, P., \& Hoffman, L. C. (2019). Effects of the addition of vinegar, weight loss and packaging method on the physicochemical properties andmicrobiological profile of biltong. Meat Science, 156, 214,

Lira, S. A. (2014). Análise de correlação: abordagem teórica e de construção dos coeficientes com aplicação. Dissertação. Universidade Federal do Paraná. http://www.ipardes.pr.gov.br/sites/ipardes/arquivos_restritos/files/documento/201909/sachikodissertacao_2004.pdf.

Marques, F. P. P., Spinosa, W., Fernandes, K. F., \& Castro, C. F. de S. (2010). Padrões de identidade e qualidade de fermentados acéticos comerciais de frutas e vegetais. Ciência Tecnologia Alimentos. 30(1), 119 126. https://doi.org/10.1590/S0101-20612010000500019.

Marques, F. P. P. (2008). Características físico-químicas, nutricionais e sensoriais de vinagres de diferentes matérias-primas. Dissertação. Universidade Federal de Goiás UFG. Goiânia -GO, 2008. https://repositorio.bc.ufg.br/tede/bitstream/tde/2889/5/ Caracteristicas_fisico_quimicas_nutricionais_e_ sensoriais_de_vinagres_de_diferentes_materias_primas.pdf.

Microsoft Excel For Windows (2003). (Realease 7.0). Microsoft, Inc. Cary, NC, USA.

Moreira, P. de A., Pinto, E. C., \& Cristina, K. (2017). Desenvolvimento de vinagre a partir de cascas de abacaxi. In: Anais do Simpósio Latino Americano De Ciência Dos Alimentos, Campinas. Anais eletrônicos... Campinas. https://proceedings.science/slaca/slaca-2017/papers/desenvolvimento-de-vinagre-apartir-de-cascas-de-abacaxi.

Netto, C. G. (2006). Vinagre brasileiro ainda está distante do padrão de qualidade internacional. Jornal da Unicamp. http://www.unicamp.br/unicamp/unicamp_ hoje/jornalPDF/ju332pg09.pdf>.

Paganini, C.; Nogueira, A.; Silva, N.C.C., \& Wosiacki, G. (2003). Beneficiamento do bagaço de maçã visando a produção de álcool ou concentrado de fibras. In: $5^{\circ}$ Simpósio Latino Americano de Ciência e Tecnologia de Alimentos, 5., Campinas. Anais... Campinas. https://www.scielo.br/pdf/cagro/v29n6/v29n6a18.pdf.

Pedroso, P.R.F. (2003). Produção de vinagre de maçã em biorreator airlift. Dissertação. Engenharia Química, Universidade Federal de Santa Catarina, Florianópolis.

Rizzon, L. A., \& Miele, A. (1998). Características analíticas de vinagres comerciais de vinhos brasileiros. Brazilian Journal of Food Technology, 1(1), 25-31.

Santos, G. C. dos., Júnior, U. G. da S., Neto, J., da Fonseca., \& Filho, E., V., de C. (208). Método alternativo de produção de vinagre com reaproveitamento de cascas de frutas. Revista Principia, 16, 62-67. http://dx.doi.org/10.18265/1517-03062015v1n16p62-67.

Schmoeller, R., \& Balbi, M. (2010). Caracterização e controle de qualidade de vinagres comercializados na região metropolitana de Curitiba/PR. Visão Acadêmica, Curitiba, 11(2), 80-92. https://revistas.ufpr.br/academica/article/view/21372/14092

Takemoto, S. Y. (2000). Avaliação do teor de acetoína em vinagres como forma de verificação de sua genuinidade. 2000. Dissertação. Universidade Federal de Santa Catarina, Florianópolis.

Tesfaye W., Morales M.L., Garcia-Parrilla M.C., \& Troncoso A. M. (2002). Wine vinegar: technology, authenticity and quality evaluation. Trends in Food Science and Technology, 13, 12-21, 2002. 10.1016/s0924-2244(02)00023-7

Tessaro, D., Larsen, A. C., Dallago, R. C., Damasceno, S. G., Sene, L., \& Coelho, S. R. M. (2010). Alcohol and acetic fermentation appraisal for vinegar production from orange juice. Acta Scientiarum Technology, 32(2), 201-205. http://dx.doi.org/10.4025/actascitechnol.v32i2.4275

Ubeda, C., Hidalgo, C., Torija, M. J., Mas, A., Troncoso, A. M., \& Morales, M. L. (2011). Evaluation of antioxidante activity and total phenols index in persimmon vinegars produced by deferent processes, Food Science and Technology, 44. e7. 1591-1596. https://doi.org/10.1016/j.lwt.2011.03.001

Veloso, C. L. (2013). Sistema de produção de vinagre. Instituto Euvaldo Lodi - IEL/BA 
Research, Society and Development, v. 10, n. 14, e84101421878, 2021

(CC BY 4.0) | ISSN 2525-3409 | DOI: http://dx.doi.org/10.33448/rsd-v10i14.21878

Viana, R. O, Guedes, K. T. M., Braga, R. A, Jr, Dias, D. R. \& Schwan, R. F. (2017). Fermentation process for production of apple-based kefir vinegar: microbiological, chemical and sensory analysis. Brazilian Journal of Microbiology $48592-601$

Viroli, S. L. M., Viroli, S. G., Carvalho, N. P., Alves, T. T., Leite, L. T., Sousa, Y. P., Bernardi, D. P. da S., Araújo, T. L, Lança, A. C., \& Silva, F. de P. e. (2021). Characterization of artisanal vinegar produced with apple peel. Research, Society and Development, 10(9), e1110917865. https://doi.org/10.33448/rsdv10i9.17865

White, J. (1971). Vinegar quality: legal and commercial standards. Process Biochemistry, 21-25. 